\title{
POLITICAL DISCOURSE: A CRITICAL DISCOURSE ANALYSIS OF THE RESISTANCE OF ISLAMOPHOBIC IDEOLOGY IN IMRAN KHAN CONFERENCE TO UNGA
}

\author{
Khushnood Arshad \\ khushnoodarshad566@gmail.com \\ National University of Modern Languages Peshawar Campus, Pakistan \\ Sulaiman Ahmad \\ sulaimanahmad@numl.edu.pk \\ National University of Modern Languages Peshawar Campus, Pakistan
}

\begin{abstract}
Sanah Waheed
sanahwaheed0099@gmail.com

Nationay Oniversity of Mlodern Languages Peshawar Campus, Rakistan age udas of political actors who dialectically produce their discoun ses for the spe ific purpose of grasping "pro-ideologies" of masses with ut giving much room to their real interests. To a great extent the manipulation of languago serves as a sturdy tool for nolitical henefits and onsequently it provides a strong base for the exploitations of the ideological assumptions of people on a large scale. A critical discourse analysis of Imran Khan's point of view on Islamophobia suggested that a good speaker always overwhelms the masses and changes the way of thinking of the public. The researchers have accentuated that Imran Khan has affected the mindset of the people regarding Islamophobia. Also an analysis has been done by the researchers of discourses examples in the Imran Khan's Speech. The researchers have explored various indicators of van Dijk in the Speech of Imran Khan. This paper aims to discuss the realization of the resistance of islamophobic ideology in Imran Khan Speech by means of language use in a political discourse, which is mainly grounded in Teun van Dijkees assumptions in critical discourse analysis. For this aim, the discursive strategies of the Pakistani Prime Minister Imran Khan during a press conference in the United Nation General Assembly held on 25th September 2019. The Speech will be examined within the context of his ideological, cultural and language background.
\end{abstract}

Keywords: Political Discourse, Power, Ideology, Critical Discourse Analysis 


\section{INTRODUCTION}

People sometimes use words which portray different meaning than the literal meaning. Individuals play with words in order to promulgate the message in a way that is unfamiliar to the common mass. Most of the time, People operate their language in order to communicate and achieve their goal in an indiwootway wather than directly/referring to the phenomenon. Every lang uage contains certain words which are $m$ ore poy en al and fled IVe tha the other worls. Lh in the domin of Discourse, the choice of the specific syntactical structure or form of the word has great importunee thun the others, created by the superior class to be communicated to the common mass through electronic and print media.

Discourse is from the Latin word "discourses", which means conversation or speech, but it also refers to any piece of spoken or written language beyond the sentence level, while Discourse Analysis (DA) is the study of a language used in text and context. Dijk (1998) defined Critical Discourse Analysis (CDA) as, the area deals with the study and analysis of a written and spoken text in order to revel the biasedness, inequality, dominance and the discursive source of power. It explores how these discursive sources are manipulated and produced within proper historical, social and political contexts.(Dijk, 1998)

To conclude it simply, the Critical Discourse Analysis (CDA) purpose is to clear the relation among discourse practice, social practice and social structures, connections that might be unclear to the ordinary people.

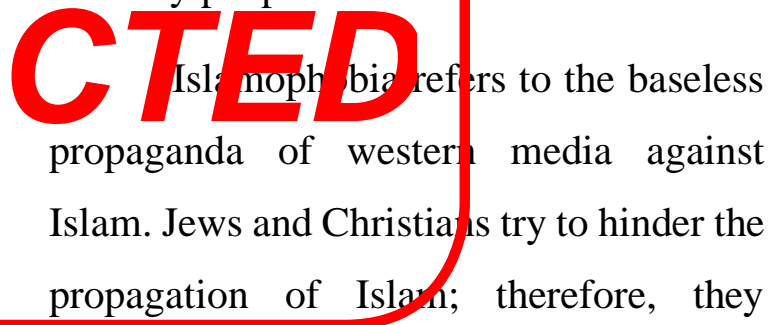
deliberately struggle to portray a negative image of Islam and want to present Islam as a religion of uncultured and barbaric people. The purpose of Islamophobia is to alienate people from Islam, to keep the people away from Islam and to show them that Islam is a religion which teaches terrorism and violates the basic rights. Islamophobia is a struggle to counter the spread of Islam and generate misunderstanding in the minds of people who want to accept Islam. Everywhere in the world, we see that there is a double standard adopted by the international 
media while portraying the problems faced by the Muslim community. The West should control the Islamophobic behavior in order to create an atmosphere of harmony and peace.

Before embarking on an analysis of the speech of the Prime Minister of Pakistan, Imran Khan, at high-level round table conference on countering hate speech, in the sidutime of Uimited ivation General Assembly meeting, held on 25th Septembe-2019, it would be very useful to

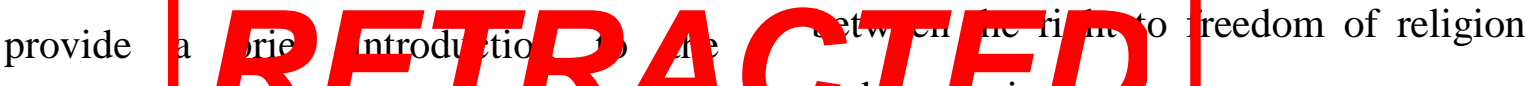
conference 4 n bruer to arralyze an contextua ize his speech. In this important Press Conference in New York, USA, Imran Khan was also accompanted by the Turkish President Recep Tayyip Erdogan as well. Maleeha Lodhi, the then Pakistani's representative to the United Nation, was also present there in the Press Conference. Maleeha Lodhi began the Press Conference and then handed over the

\section{REVIEW OF RELATED LITERATURES}

In this paper, the researchers have provided a detailed review of the available literature related to Dijk's Model (2007) and the role of Political Discourse Analysis have been discussed. mic to Prime Minister Imran Khan, Who talked about Islampohobia; one of the most alarming threats to the peace of the world. The Premier addressed both the causes and consequences of this phenomenon to the world. The Premier, in his speech, also highlighted the importance of using the platform of United Nation for addressing such issues. In the same Press Conference President Recen Tayyip Erdogan of Turkey also explained the menace of Islamophobia and echoed the UNGA for bringing balance hd $\mathrm{xp}$ - scior

The purpose of this study is summarized in two patts as follows:

- To highlight the indicators of Van Dijk's model in Imran Khan's speech in the anti-Islamophobic conference,

- To explore the resistance of the Islamophobic ideology in Imran Khan's speech in the conference.

Sajjad (2015), in his article, states that Political Discourse Analysis (PDA) pointed the liberal docket of political actors who enunciate their expatiates for the specific agenda to attract the thoughts of a 
group of people without addressing their real problems. Most of the times, the deliberate use of the speech is used as a tool to achieve political supremacy and as a result, it provides a source for abusing of the "thinking outcomes" of the people. Likewise, the former United States President Barack Obama used an effective and smart language in order to divert the ideology of the East and Muslim world. Barack $\mathrm{Ob}$ ma succeeded in prevailing the interests of th $\mathrm{O}_{\mathrm{it}} \mathrm{a}$ State of AD eri and her allics by nawhe of beace, prosperity, democracy, economical assistant an change.

Similarly, Baram (2010) concluded in his research that the way we feel, understand and assume a language is a basis for the establishment of individual groups and social relations. The Sociolinguistics has explained the link between the language and its impact on the people's mind. A discourse can be originated from many sources such as eager for power, for cultural influence, social background or for regional and social status. Likewise, Turkish president Recep Tayyip Erdogan used discourse analysis in the world economic forum summit (2009) in order to achieve political and economical targets. In Davos, the
Turkish president, in a debate with Israeli President, influenced people by his language. He attracted the mindset of the people (specifying the Muslims) by the sentences he used in the said dialogue. After that Mr Erdogen was considered as the most influential political leader in the Muslim world.

In his research Sharndama (2015), while analyzing the in augural speech of Muhammad Buhari, says that the inaugural speec es he exposure of future ambitions, aims and faiths in the newly formed governments. Si milarly, the speech of Muhammad Buhari created a discourse about his intentions ideas and plans on the minds of the public. He diverted the thoughts of the people regarding his priorities about good governance, foreign policies and relations, corruption and other facilities. Thus it can be concluded that an inaugural speech varies from other political speeches.

Kareem (2001) claims that Communication through social media has become a never-ending method of exploring and sending thoughts and opinions in the arena of all subjects. He further stated that the "freedom of expression" should have certain limits otherwise it will become a "hate speech". 
So freedom of expression must have certain parameters, in which an individual is not supposed to hurt any other sentiments or rights. Critical Discourse Analysis (CDA) is discussing rationally the opposing ideas in order to find the truths. The social media can easily affect the mindsets and hence ideologies of the people sometimes give devastating results in response to hate speeches.
Athar (2018) concludes that it is not universal or academic perception which can construct an established perception and to remove gender discrimination in an environment. In order to legalize their stances, the individual of each group used a separate discussion structure. Through Van Dijk's model of ' 'US', and ''them' 'It has riveted that different way of thoughts prevails in the society regarding gender discriminations.

\section{METHODS}

\section{Design}

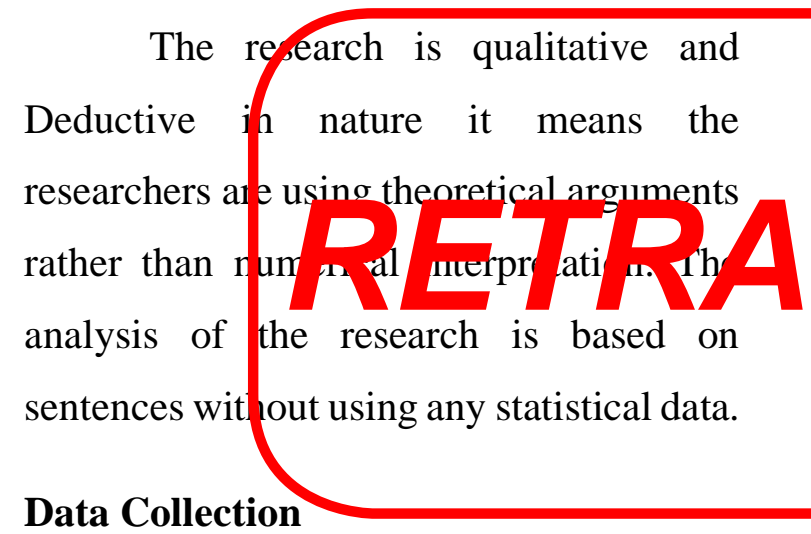

The researchers worked on the speech of Prime Minister Imran Khan in the sideline of United Nation General Assembly meeting, held on 25th September 2019. The script of the Speech was taken from the video and audio sources available on the internet.

\section{Theoretical Framework}

Dijk, a scholar $\mathrm{n}$ the fields of text linguistics, discourse ana yst and Critical Discourse Analvst, started his work in the ield of $x t$, ramn ar $y, y$ th e time when the text was only analyzed thr ugh Chomsky's grammar. According to D jk (2007), while analyzing a text, cognition of a text is as important as the structure of a text. From the cognition, he means the mental representation or the mental structure of a text. Later in his studies, he further added that though the textual and mental structure is necessary for looking into a text but there is a third dimension of the text as well, which he called the social structure. Thus, he presented his Three Dimension Model 
in the field of Critical Discourse Analysis for exploring a text completely. His works focus on the psychological perspective of a text rather than the simple direct meaning. He did much of his work in the area of discourse on the basic microstructures of a text which an individual can not observe generally in a text.
1. Evidentiality

2. Actor Description

3. Authority

4. Disclaimer

5. Generalization

6. Irony

7. Victimization

8. Presupposition

9. Hedging/Vagueness

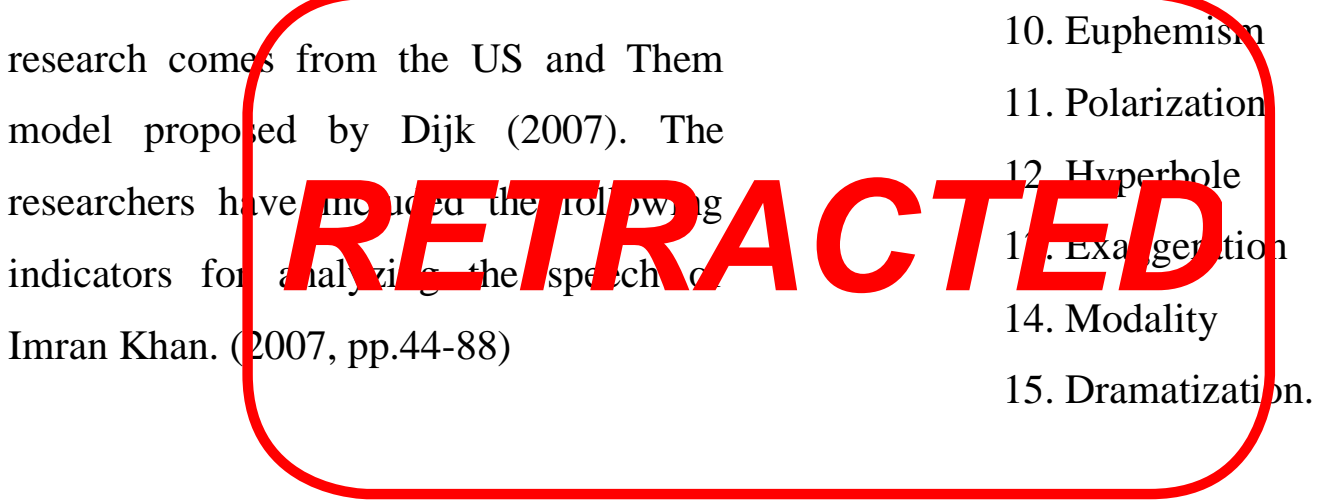

\section{RESULTS AND DISCUSSION}

\section{General Discussion}

Imran Khan welcomed all the participants. He wanted to express his views regarding Islamophobia. According to Imran Khan, Islamophobia is a serious threat and it will have far-lasting impacts in the current global society. He said that after 9/11, the terrorist activities are linked with Islam, especially the suicide attacks. Before 9/11 Ancients, there were a lot of suicide attacks, carried out by the followers of other religions but no one blames those religions.
Imran Khan urged that there is only one Islam and terrorism has nothing to do with Islam. He further emphasized that the world has no idea about the white supremacists that attacked the innocent Muslims in Christ church, New Zealand. Thus Islam cannot be linked with terrorism as it will create a lot of ambiguity and confusion. Imran Khan pointed out not all the Muslims should occur of the act of individuals. There are many reasons that have hurt the sentiments of the Muslims, like the scripts of Salman Rushdie, 
which contain blasphemous materials. Likewise the awful and blasphemous activities of the certain people in the west, have created concerns in the Muslim world. But according to Imran khan, the people in the west are unaware of the fact that how much we have a love for Our Holy Prophet (PBUH). Also, Islam is not explained to the west in the best way, and the west does not know how painful is tirat witerl some disgraces Oy Holy Prophet (PBUH). Imran khan stressed that the Muslim leader should play their ro e ir thi $\mathrm{re}$ ard an th $\mathrm{m}$ ssa of should be conveyed crearly that dasphemy hurts the Mi slim, as holocaust hurts Jews.

Thus, vhile living in a society, its entire member should understand each other. Blaming Islam for terrorist activities and Blasphemy are the two main causes of Islamophobia and these two causes should be addressed properly.

\section{Linguistic Discussion}

\section{Evidentiality}

According to Dijk (2007), evidentiality is the proof and evidence that a speaker provides in the support of his stance during his/her speech in order to influence the audience (Dijk, 2007, p.52).
The PM Khan, in his speech, has many proofs and evidence in order to produce an impact on the minds of the audience. Some of the examples of the proofs used by Mr. Khan are:

He refers the incidents of the Holocaust and says, we should all convey to the Western leaders, Especially the Western leaders that the way, the sensitive way, Holocaust is treatea in the West because it gives pain to the Jens people and quite rightly it should be, the World should be sensive vith $m$ vhot gives them pain (Khan, 2019).

Thus, he points put that the killing of millions of Jews wac anjust that is known as the Holocaust. In the same way, the islamophobia hurts the Muslims like Holocaust hurt the Jews.

In his speech, Mr. Khan also urges that after 9/11 discrimination was created regarding Muslims. He explains that all Muslims can not be targeted by the act of individuals. So there should be no islamophobic ideology by the act of a single person.

Mr. Khan says I remember after 9/11, I get a phone call from the Western Journalist and he said aren't you really shamed of what is happened. There are 1.3 
Billion Muslim, $m$ I supposed to be ashamed of what anyone does and any Muslim does? (Khan, 2019)

Similarly, Mr. Khan gives evidence of the terrorist attacks of the non-Muslims on the Muslim community. Mr. Khan emphasizes that Islamophobia has drastically raised attacks against Muslims. So by referring to the New Zealand mosque attack, he has nicely explored the issue, Islamophobia. He added, What about the White Supremg ists who walk into a mosque and kill 49 worshipers in New Zealand. What is tha going to do with religion? (Khan, 2019

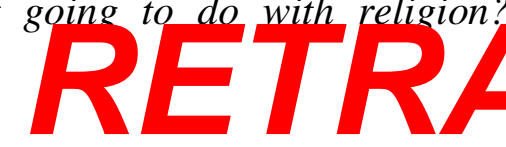

Mr. Khan castigates Salman Rushdie controversial book The Satanic Verses by these words that clearly explains the islamophobia character.

I have seen this since the awful man Salman Rushdie produced book called The Satanic Verses, it was mocking, ridiculing our Holly Prophet Muhammad PBUH (Khan, 2019).

\section{Actor Description}

Dijk (2007) explains the actor description as; that the role of an actor is very important. The actor describes the people/audience in $U s$ and Them in political discourse analysis. The speaker/actor demarcates two various groups and highlights the positive aspects of $U s$ and negates the arguments of Them. (Dijk, 2007, p.51).

In his speech PM, Mr. Khan emphasizes that Us (the Muslim leaders) are the victim of Islamophobia and Them (West) are having a hatred approach towards Islam unjustly. Thus, Mr. Khan categorically suggests that the Muslims should present the positive image of Islan to them vis-a-viz to the West, to counter the slamophobia.

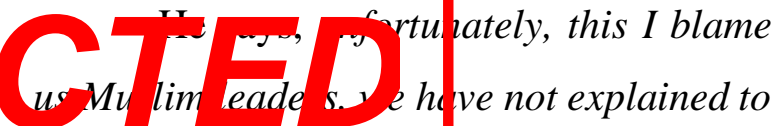
the Western societies, ho v painful it is when a Prophet is maligned, nocked ridiculed it causes (Khan. 2019)

\section{Authority}

Dijk (2007) explores the authority is a powerful forum/group/organization/person that can play a decisive or an arbitrator role in a discussion and the speaker presents this authority in the support of his argument. The authority latterly is considered as moral or expert (Dijk, 2007, p.63).

Mr. Khan in his speech describes the UN as the authority that can play a role for inter-religion harmony to vanish 
islamophobia and says, So this is the greater forum the UN all world leaders are here and I will be talking about this is in my speech on Friday as well but I feel that it is important that us Muslim leaders convey these two things because all it does, it creates fishes amongst creating human beings and anything that creates fishes this is the forum where we should try to unite humanity (Khan, 2019).

\section{Disclaimer}

Discourse of

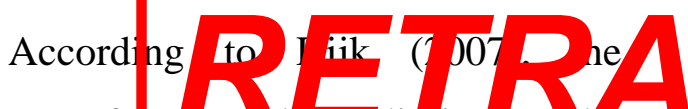
audience from the claim of the speaker because he/she does not consider their responsibility for a particurar act and neitner respective ideologies. For this purpose, the speaker uses two different kinds of clauses in order to support his/her stance without hurting the sentiments of the audience. Furthermore, the speaker elucidates his/her views and refrains to target as a whole; nevertheless, he/she conveys his/her message (Dijk, 2007, p.50).

Mr. Khan in his speech argues that When I first arrived in England as an Eighteen years old there was a film called 'Life of Brain' a comedy by Monte it was a character about Jesses Christ (Khan, 2019).
Thus, Mr. Khan has shown that not all the followers of other religions are responsible for Islamophobia; rather Christianity was also targeted by the same extremist.

\section{Generalization}

Generalization, According to Dijk (2007), is a phenomenon in which speaker generanzes arantissuetdiscourse by a specific example from the in-group Us. Thus by giving examples he/she tr es to make clear S stand in a com n vay (Dijk, 2007,

In the speech of In ran khan we can find generalization in the se lines, this issue, the biggest damage to Muslim as that after 9/11, terrorism was associated with Islam. So Islamic terrorism, Islamic radicles and constantly these words were used by leaders. Western countries explaining that you know, 9/11 terrorists and any act of terror that took place after that...(Khan, 2019).

So in his view, the Mr. Khan has made it clear that the label of terrorism was generally applied to the Muslims in a bizarre way and Muslims are suffering generally due to the act of an individual. 
Irony

Dijk (2007) explains irony as, a tool that a speaker uses while producing a discourse, in order to support the claim of "in group" by an argument containing a slight sense of humorous and taunt (Dijk, 2007, p.76).

As Mr. Khan says in his speech, in especially suicide bombing, because we hurt, these regularly, we ham inese common (terrorising) hat you know Muslim is indulging in st icide attack because they will have virgins in he ver 7 hissor of $r$ ins hs 1 kept going on

In these lines, Mr. Khan has mocked the false concep of the West by arguing that west has a false belief that Muslims are involving in suicide attacks because they will get virgins in the heaven which is not true. And this misconception of the west accelerates Islamophobia.

\section{Victimization}

In victimization, Dijk (2007) says that the speaker through his discourse divides the people into in-group and out group and further he/she shows the in group as a victim of the sufferings of the out group (Dijk, 2007, p.84).
In his speech Mr. Khan has shown Pakistani as a victim by these words, I have seen Pakistani community in England, marginalized in Manchester areas and Birmingham and we have seen radicals coming out of these communities, and we have seen the same process in Europe because of Islamophobia (Khan, 2019).

Apart from this, Imran khan portrays the islamophobia and victimization of Islam by saying, "What about the White Supremacists who walk into, kill 49

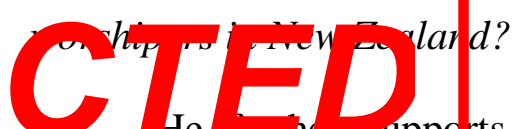

Muslims are the victims of the prejudiced behavior of the west by this sentence, how paingut it is when a Prophet is maligned, mocked ridiculed. Why does it cause so much pain to us? Because the Prophet lives in our hearts and we all know that the pain of the heart is as far far far greater than physically pain (Khan, 2019).

\section{Presupposition}

Dijk (2007) defines presupposition as the discourse produces by the speaker containing and explaining the already known information to the listeners in order to strengthen the argument of the "in group" (US) (Dijk, 2007, p.82). 
In the Speech of Mr. Khan, one can observe presupposition in the argument that no religion has anything to do with terrorism (Khan, 2019).
It can be assumed from the above argument that Islam is not linked with terrorism and Islamophobia is clear biasedness towards Islam.

\section{CONCLUSION}

The researchers have arranged, presented, interpreted and analyzed the

vi. Imran Khan has successfully influenced the views of the West discourses collected from the Prime Minister regarding the Islamophobia. By Imran Khan sreech.
Fe taken as a cor analysis, multiple points may
i. A gopd statem the
and the needs of the public and
listeners, thus he/she chooses proper
words andimims.

ii. The speakers, usually the politicians, divert the mindset of the public by various means, techniques, arguments and sources.

iii. The research is based on political discourse analysis.

iv. Prime Minister Imran Khan attracted the attention of the general public and has influenced the thoughts of the people, especially the Muslims.

v. If the speaker utilizes strong and effective sentences in the speech then he/she can easily achieve his/her goals. vii. A lot of example of discourses have been collected, opserved, interpreted and investigated.

viii. Prime Minister Imran Khan has frequently used the various discursive strategies in his speech such as actor description, authority, disclaimer, generalization, irony, victimization and presupposition. However, the disclaimer, evidentiality, irony were mostly used by Prime Minister Imran Khan.

ix. While some of the Dijk's (2007) indicators were not found in the speech of the Prime Minister Imran Khan, that include vagueness/Hedging, Euphemism, 
Hyperbole, Exaggeration and

Dramatization.

\section{REFERENCES}

Awan, I. 2016. Islamophobia on Social Media: A Qualitative Analysis of the Facebook's Walls of Hate. International Journal of Cyber Criminology. Vol. (10). Issue 1, 1-20.

Athar, S. 2018. Gender Positioning in Academic Setting In Pashtun Society: A Critical

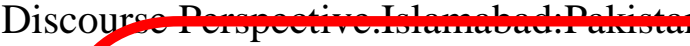

Bayram, F. 2010. Ideology and Political Discourse: A Critical Dis fourse Analysis of Ercogan's Political Speech. Vol.7, 23-40.

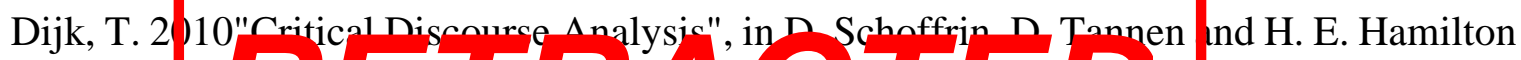

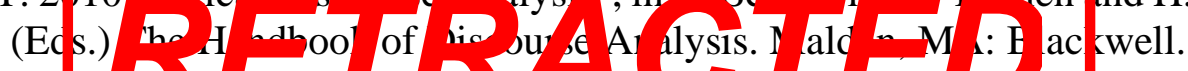

Dijk, T.A 1991. Racism and the press. London. Routledge.

Dijk, T. A. 1993. Principles of critical discourse analysis. Discourse and Society, 4(2),24983.

Dijk, T. A. 2007 Ideoloov and discourse- A multidisciplinary introduction [Ebook]. Retrieved from http://www.discourses.org/UnpublishedArticles/Ideology\%20and\%20discourse.df

Fairclough, N. 1999. Critical Discourse Analysis: The Critical Study of Language. London: Longman.

Sajjad, S. 2015. A Critical Discourse Analysis of Barack Hussein Obama's Political Speeches on the Middle East and the Muslim World. International Journal of Linguistics. Vol. 7, No. 1.doi:10.5296/ijl.v7i1.6856. 